\title{
The Role Of Ideological State Apparatuses In Identity Formation In Qaisra Shahraz's: The Holy Woman
}

\author{
Amna Saeed \\ \& \\ Azher Khan \\ Department of Humanities \\ COMSATS, Islamabad
}

\begin{abstract}
This research aims to critically analyze the role of Ideological State Apparatuses, defined by Louis Althusser, in identity formation of Zari Bano, the protagonist in the novel "The Holy Woman" written by Qaisra Shahraz. According to Althusser, ideology functions through ISAs which change individuals to ideological subjects within capitalist society. This study focuses on the influences of the cultural ISA, the political ISA and the family ISA on the character of Zari Bano. The study also analyzes the moments of 'interpellation' by critically evaluating the text of the novel and reveals how the characters act in certain ways and blindly accept certain beliefs and ideologies. The findings of the research indicate that the ISAs play a crucial role in formation of individuals' identities and the socio-cultural / political ideologies set double standards in a patriarchal society, particularly for women, which are difficult to challenge. The research is significant as it deals with the issue of passive discursive ideologies at work in setting up different norms and values in a patriarchal society and how these are given the status of natural laws of life to be followed blindly by the social subjects. This research study is limited to the analysis of interpellation and ISAs only on Zari Bano and the characters closely related to her within the first part of the novel. The study is replicable and may draw attention of the scholars to investigate the role of ISAs other than those in this paper and explain action and reactions of the characters involved.
\end{abstract}

Keywords: Interpellation, Identity Formation.

$$
\begin{aligned}
& \text { تلخيص }
\end{aligned}
$$

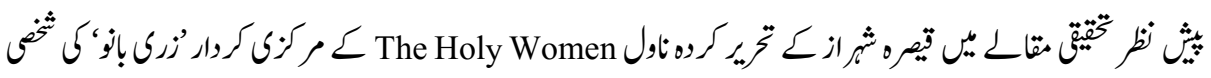

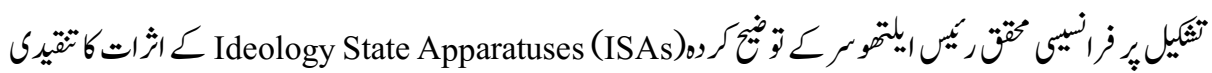

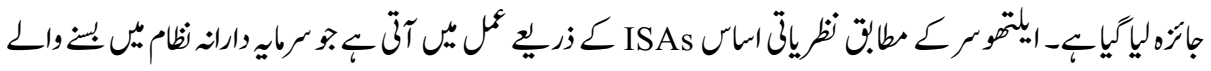

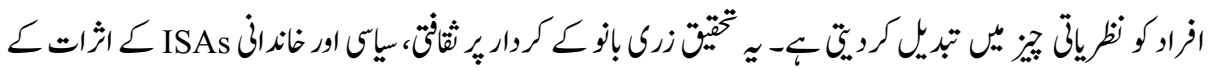

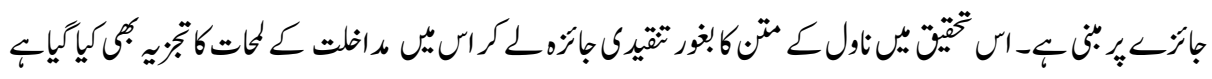

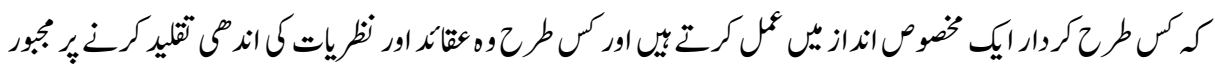




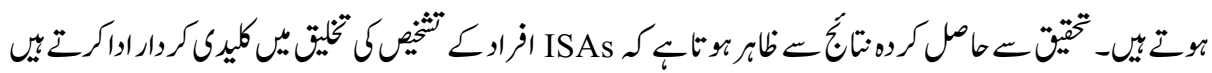

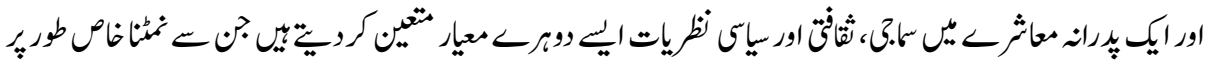

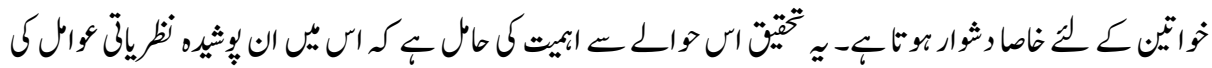

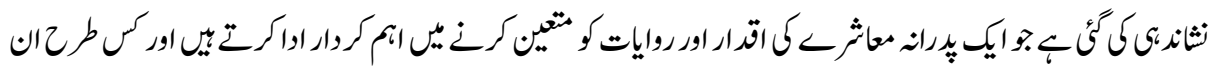

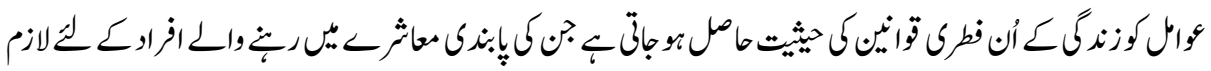

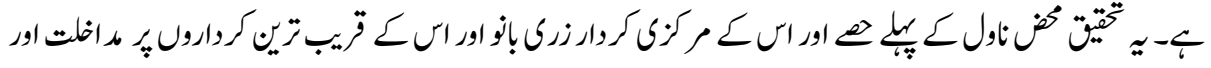

$$
\begin{aligned}
& \text { LISAs }
\end{aligned}
$$

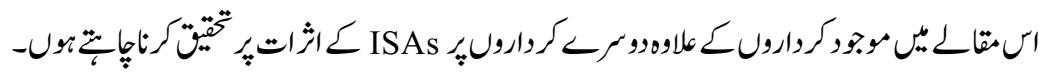

$$
\begin{aligned}
& \text { كليدى الفاط: مراخلتشثاختكى تثنيل }
\end{aligned}
$$

\section{Introduction}

In a patriarchal society, as that of Pakistan, men and women are positioned as alienated subjects with well-defined social roles. The social institutions within the society, such as school, family, religion, law, culture and media turn men and women into mere instruments of social function instead of free beings. Such social functions defined by socio-cultural ideologies create gender inequality in society (Qadir \& Riaz, 2015). These social entities act under the influence of certain ideologies that are formed through various discursive practices prevailing in the society. In other words, individuals are controlled by the prevailing set of morals, standards and realities of the society (Trudgill, 1974). Women in specific become victims of these patriarchal prejudices and suffer from physical, psychological and social violence at the hands of men (Tarar \& Pulla, 2014). Such violence originates from the power practices of emotional and physical control of husbands over wives, fathers over daughters and brothers over sisters, shaping women for the roles and social functions defined by men in society (Cixous, 1986; Walby, 1990; Isran \& Isran, 2012). The problems become even worst for women when they internalize these roles and synchronize them with their performative roles, thereby finding it natural to be oppressed (Butler, 1988). Therefore, a study to explore effects of various social relations on women and their impact on their lives is significantly important.

The present research is an attempt to investigate the role of Ideological State Apparatuses, defined by French Philosopher Louis Althusser (2001), in identity formation of the protagonist of the novel The Holy Woman (2002) written by Qaisra Shahraz. The novel voices the feministic version of the fake ideals and standards of the Pakistani patriarchal society. The novel's lead character, Zari Bano, is influenced by the ruling ideological practices prevailing in the society of Rural Sindh and she ends up with no 
option but to accept the ideology thrust upon her. The study also analyzes the moments of 'interpellation' that encourage the characters to act in certain ways which in turn make them suffer due to uncritical acceptance of the ideological dynamics of their family traditions, cultural values and social system.

Qaisra Shahraz is a Pakistani English writer who has written about the struggle of women against the patriarchal structures/practices of the society. In her novel, The Holy Woman (2002) she narrates the story of a modern feudal family, which has moved from its home village to the neighboring city in Rural Sindh. This physical movement towards modern life doesn't change the feudal mentality of the male head of the family, Habib Khan. When his only son dies, he forces his elder daughter, Zari Bano to marry with Holy Quran and become his heiress, in order to keep his land and property within the family. The novel is a narrative that uses the symbol of holy woman to highlight the issue of discrimination against women in Pakistani society and develops an understanding of patriarchal structures and their impact upon the life of Pakistani women. In our society, the powerful religious and cultural customs influence our lives and create tension within the family relationships. Most of the time, it is women who suffer in a male- dominant society. The novel deals with this male dominance and the tension between male and female members of the society (Arafath, 2014).

The research is significant as it deals with the issue of highlighting the passive ideologies at work in setting up different norms and values in a patriarchal society. These sociocultural/political ideologies set double standards in society which create injustice and suffering of different groups in society which is difficult to challenge or raise a voice against. The reason to choose this particular novel is that it represents the powerful social structures, feudal traditions and customs, and the ideologies that shape the people's lives.

\section{Female Identity Construction}

We define ourselves in relation to other people. The identities we fight over are produced in what contemporary theorists have understood as an economy: a shifting interchange of meanings and desires, a perpetual give and take of values and images. In this way, the relation between self and other is highly charged and volatile. When we represent ourselves, we inevitably, even if tacitly, represent others (Fuery and Mansfield, 2000, p. 144)

Human identity is not subject to an individual as s/he is seen by him/her own self; we tend to see ourselves not just how distinct we are from others, rather in connection to qualities that we impart to others, as individuals from particular gatherings, societies, nationalities and ethnic groups. Every one of us is a unique individual due to the similarities and differences we share with each other. Hence, an individual's identity is not originated from within the self, but is constructed and maintained through a series of 
contact, communication and interaction with other people in the society. "Identity" is defined by Burke and Stets $(2009$, p.3) as:

What does it mean to be who you are? An identity is the set of meanings that define who one is when one is an occupant of a particular role in society, a member of a particular group, or claims particular characteristics that identify him or her as a unique person.

According to the above definition, "identity roles" play a significant role in determining an individual's place in the immediate context of its society, and his/her behavioral outcomes/patterns developed by those roles. For instance, an individual has at the same time multiple roles in society; she may be a daughter, a mother, a sister, a teacher or a student. Living in a society as a subject of it, one's identity keeps on shifting in between the many roles one has to perform in a specific socio-cultural context. All these different classifications that individuals hold in relation to their place in the society are their identities. So, the person is a combination of numerous identities relying on his/her place in the society, attributes of the culture wherein he/she is raised and the collective norms of his/her immediate gatherings.

The construction of identity as subject formation in society is an important discursive process in an individual's life. John Lye (1997) associates the term 'subject' with the individual, who is a socially and discursively structured symbolic being who comes into existence through socio-cultural interaction in life. As for identity formation, he asserts that social subjects are social constructs, who self-define themselves with their relation to their groups' ideology, their role in the society, their close relations, and their shared practices with sub-social gatherings and with their overall socio-cultural environment. Ochs (1993) holds that social identities are formed by social interactions and influences of the individual with other members of society and a failure to achieve harmony in them may result in an identity crisis.

Identity, then, viewed as a social process of the making of self, is basically a social and discursive construction and the rules to be who and not to be who are determined according to the standards set by the powerful norms/values of the society. According to Foucault, the social dynamics are representatives of power practices, which not only influence the subject, being the center of social system, rather construct it.

The individual is not to be conceived as a sort of elementary nucleus, a primitive atom, a multiple and inert material on which power comes to fasten or against which it happens to strike, and in so doing subdues or crushes individuals. In fact, it is already one of the prime effects of power that certain bodies, certain gestures, certain discourses, certain desires, come to be identified and constructed as individuals. (Foucault, cited in Fuery and Mansfield 2000, p. 174) 
Hence, the subject itself is a power construction and the ideals, customs and norms of the social network determine whether something is accepted as right or wrong. Power influences a person in many forms; it can be political, cultural or ethical, and it governs the position / role of a person in the society, the profession s/he adopts, the way s/he dresses up, the form of language s/he uses, but paradoxically the person's own will of having power in society shapes the very structure of this power dynamics.

When it comes to women, their social identity is constructed through active as well as passive socio-cultural influences since childhood that they don't even find the oppressive discourses shaping their lives as unnatural. On the contrary, since the process shapes them so naturally they themselves become agents of their own oppression (Lemley, 2005). Beauvoir, while distinguishing between "gender" and "sex" and the construction of gender identity asserts that "one is not born, but rather becomes, a woman" (1997, p.295). This process of becoming shapes women according to social needs and practices and labels them as women. Most commonly it is the men in the society that label the roles of women in society and in a patriarchal society women do not have many choices to define for themselves who they want to be and how they want to lead their lives. Patriarchal practices focus on the sex or biology of men and women and ignore the consciousness of "gender" (Heywood, 2003). Women are hence perceived as weak, frail members of the society and are considered fit only for the household.

\section{Interpellation and Identity Construction}

The term "interpellation" was introduced by Althusser to explain the ways in which ideas get into our heads and have such an effect on our lives that we believe they are our own. Interpellation is a process in which people internalize their socio-cultural values through ideological "hailing" and transforming into subjects. Ideology thus, through the process of interpellation, in a sense 'recruits' subjects among the individuals in a society and 'transforms' them into subjects who unconsciously are trained to abide by the norms of society by a force which they consider to be a natural part of their lives (Jorgenson \& Philips, 2002).

Through this process people are brought into the dominant ideologies that are their attitudes regarding their society and the issues prevailing in the social structures such as class, gender, culture, religion, politics, law and family. Whether or not they accept their place, individuals are brought directly into their relationship to the power of the dominant within these hierarchical structures. Medina (2005, p. 168) explains the idea of "interpellation" as "the formation of identity through the address of the other... A kind of hailing that has the formative power of configuring one's identity in a particular way and of making one accept this concrete configuration as what one is." 
Even before birth, the fetuses become aware of their mothers movements, and tone of voice and start associating with them as a natural course of developmental events (Grimwade, Walker, Bartlett, Gordon and Wood, 1970). After a child is born into a certain socio-cultural environment, it is "expected" to become somebody who conforms to the prescribed standards of the society and accepts its already determined role / position. Gender roles are immediately inflicted upon children at the time of birth when exclaimed "it's a boy / girl!" Children are "hailed" as "subjects" from an early age to keep up particular behavioral examples that are connected with their sex. The most intriguing thing in the process of "interpellation" is that the subject is unwittingly made to believe that all these power dictates are obvious, natural and always right. Walker (1999, p.440) states:

Indeed, families begin to socialize gender roles even in delivery rooms-boys are dressed in blue while girls are dressed in pink (or other colors that are symbolically attached to gender). From the moment that a baby enters the world it is inundated with symbols and language that shapes its conception of gender roles and gender stereotypes.

Althusser (2001) explains that interpellation occurs in two ways, through repressive means and through ideological means. The former happens through 'violence' and the latter through ideas. Further, there are different "Apparatuses of the State" (or governing powers) that guarantee interpellation; Repressive State Apparatuses (RPAs) include armies, police, prisons and governments that maintain power through the means of force, and on the other hand, Ideological State Apparatuses (ISAs) operate through ideas, attitudes and behaviors and include social institutions such as the family, the school, the media, etc. These power sources help the governing authority to establish particular standards, ideals, beliefs and values to govern the people. For instance, the governments devise the syllabi of educational institutions to make learners unconsciously internalize the particular ideology of their society. Hence, we are an embodiment of our culture and society and our identities are constructed through ideologies in such a manner that we believe that the power hierarchies that control our mind through various apparatuses are always right.

Many literary analysts have applied Althusser's theory on different literary works/genres. Ambayec (n.d.) applied Althusser's theories on "Harry Potter" written by J. K. Rowling and examined role of the school of magic in the wizarding world, serving as the ideological state apparatus and the Ministry of Magic, the acting government in the novel, serving as the repressive state apparatus. Her findings proved that ideology has a huge impact on the way of thinking of individuals as they become subjects of interpellation. Assemi (2012, et. al) conducted a research on application of Althusser's ideology on James Joyce's short story "Clay" and investigated the influence of ISAs of culture, religion, patriarchy, communication on the protagonist of the short story. 
Sadati (2013) examined Amiri Baraka's poem "In Memory of Radio" to expose the negative role of the repressive White ideology and the function of radio programs as Ideological State Apparatus in identity formation of African Americans in a society 'hailed' by White Americans. His study revealed the hidden functions of the dominant White ideology and hidden structure of power. Barua (2014) analyzed the 'Ideology' as a theoretical framework from various perspectives and its location within the broad 'nexus' of theoretical paradigm of Marxism, Post-Colonialism and PostStructuralism. In this article an attempt is made to describe the nature of 'ideology' and how individual gets converted to subjects in the hands of the power structure, by use of the tool 'ideology'. Kiziltas (2014) examined 'The Doll's House' by Katherine Mansfield with emphasis on ideology and ideological state apparatuses, particularly of family and school, in raising children and determining society's standards. The analysis revealed that the ruling class, through its ideology, shapes society according to its own purposes and objectives and 'hail' people to act as subjects under its prescribed rules. Tyagi (2014) applied Althusser's theory on Doris Lessing's first novel 'The Grass is Singing' and found that ISAs play a key role in forming an individual's imaginary identity that is unrealistic and gives him/her only false delight. Davis (n.d) conducted a research study on Robert Penn Warren's first novel "Night Rider, the story of Percy Munn", set during the Kentucky Black Patch War of 1908 and explores, with the help of Althusser's concept of ISAs, the story's dramatic tension and ideological class struggle between capitalism and Agrarianism.

\section{Research Questions}

Q.1. How do Ideological State Apparatuses function to interpellate and form an individual's identity in a society?

Q.2. What are the different Ideological State Apparatuses that affect the life of Zari Bano in accepting her fate as a 'holy woman'?

Q.3. How does the novel depict interpellation of the characters in accepting certain ideas, beliefs and ideologies by submitting to the dominance of the powerful?

\section{Methodology}

The present study is qualitative in its nature and the contents of the novel "The Holy Woman" are critically analyzed with socio-cultural perspective after a closed reading of the text. The text of the novel is critically examined by reflecting upon the Ideological State Apparatuses which directly influence Zari Bano's life. The study is limited to identifying the family ISA, the cultural/social ISA and the political ISA in the text that establish various norms and beliefs of Rural Sindh's society for interpellation of Zari Bano as a subject. Further, it is limited to the first part of the novel only that ends with 
Zari Bano's acceptance of her role as the holy woman.

The study also examines the novel by looking at the following interpellative moments in the narrative:

1. where the characters behave in specific ways and accept certain values or things as normal;

2. where the characters of the novel consciously resist the ideological forces;

3. where the characters vocalize socially constructed ideas / concepts as simple facts;

4. where the characters accept pre-existing roles/truths. (McGee, n.d)

\section{Data Analysis and Discussion}

\section{The Socio-cultural ISA}

Zari Bano, the protagonist of Qaisra Shahraz's novel "The Holy Woman", is an educated and modern woman. She is a feminist and member of an organization which is working for the rights of women. She is a confident girl who even does not care to cover her head with 'dupatta' even when her younger brother Jaffar asks her to do so in the opening scene of the novel at a village 'mela'. Here, Althusser's concept applies that she is "hailed" into a subject position that she ought to cover head with her dupatta in the presence of male strangers. Jaffar vocalizes this typical attitude of Pakistani men which shows his interpellation as the custodian of women of his family:

Dearest sister, I wish you would make sure that your scarf manages to stay in place on your head when you are outside in a public place.... Look at your hair! Don't you ever tie it up? It is everywhere! It is not good for a woman to be seen like this. Men, especially Badmash men, give women looks when they are as beautiful as you. You look so wanton! It creates a very bad impression. Not only of you, but of us and our father. Only naughty women do that sort of thing.... It is not good for our izzat ( p.13).

However, Zari Bano confidently replies, "So what if my dupatta fell down for a few seconds? Have you never seen hair before?" (p.13) Her attitude shows her resistance towards male dominated ideological norms in the society. Also when Zari Bano is seen standing alone at the 'mela' with her 'dupatta' around her neck, she is seen by Sikandar as a non-traditional and modern woman. Zari Bano is a confident young woman who is interpellated to believe that she will not be treated wrongly by the male members of her family because of her being educated. Her education develops her conscience as a free woman as compared to other women in her surroundings. Her confidence is visible in the following words which she utters "... I am a free woman. I will decide if I want this or any other man. This is why ten years have elapsed and I have still not married. You 
shall probably marry before me, and I will be an old maid, she joked." (p. 16-17) Zari Bano's education does not empower her enough to take complete control of her life. The freedom she thinks she has acquired through education is as limited as that of any other woman in Pakistani society with no qualification. She remains unable to escape the ideology of honour which is imposed on her by the male members of her family. This invites Althusser's theory that describes how the powerful agents of social structures interpellate their subjects through their ideology. Despite being an active advocate of women rights and a member of an organization working at her University, Zari Bano is unable to challenge the decision made by her father. It is because of the centuries old oppression and marginalization that interpellates women as subordinates and inferior members of the society. Under the control of patriarchal society's ISAs, men colonize women and treat them as 'weaker sex'. This ideology is unchallengeable, even by educated women, like Zari Bano, who expresses her views as:

I woke up one morning to find out that books, feminism, campaigns and education are all utterly useless against the patriarchal tyranny of our feudal landlords. Stupidly I had convinced myself that as an educated, urban, upper-class woman, I was different to those 'poor' women, lower down the strata of our society (p.171).

The above utterances show that Zari Bano accepts the fact that nothing can change the mentality of her male guardians. This proves that the patriarchal ideology has had a huge impact on the way of her thinking and she becomes a subject of interpellation wherein a socially created reality is presented as 'truth'.

Zari Bano's feminist views are also contradicted by her decision of becoming a 'Holy Woman'. The situation is ironical as she herself is fighting against the oppression and marginalization of women. Her awkward situation is revealed when she offers the following explanation to her teacher and colleague:

I could have refused. I could have turned to hundreds of people for help, if I had wanted to. I could have married my fiancé, if I had wanted to. But I didn't at the end, for the same reason thousands of other young women in our patriarchal society...For our izzat's [honour] sake, and our family's honour. (p.173)

In terms of Althusser's concept of interpellation, the notion of social ideal of "holiness" in a woman is "hailed" upon Zari Bano. After becoming the holy woman, Zari Bano starts wearing burka, against her will, as a socio-cultural obligation to her new identity. Initially, she expresses her frustration on wearing burka; "Can any woman look lovely in this garment? I loathe this clothe.... It burns my body.” (p.144). However, as the time passes, she gets interpellated and burka becomes a part of her daily routine. 


\section{The Political ISA}

Seraj Din, the grandfather of Zari Bano, acts both as family as well as political ISA who is a product of capitalist interpellation. The ISA of the capitalist society interpellates him as the decision maker (as head of the family). His capitalist ideology is evident in his condemnation of the decision of Zari Bano's mother to send her to her suitor's home in Karachi for a short visit. Siraj Din considers it as an attempt to challenge the traditional customs of the Rural Sindh society; "Are you telling me, Shahzada, that my young, unmarried granddaughter has gone to stay, all alone, in a strange family's home and is in the company of a single young man?" (p.35).

The utterance shows his feudal mindset which considers 'women' as an entity and embodiment of the family's honour. Althusser suggests that when interpellation is thorough then those in power are "always already" powerful. Siraj Din is interpellated with the ruling class ideology and politics that provokes in him a sense of stubbornness to remain in power irrespective of taking into account his family's desires and happiness. He condemns Zari Bano's mother and reminds her of the significance of their feudal values and traditions to their clan:

Alongside our land, our wives and daughters, our izzat - our honour - is the most precious thing in our lives. We never ever compromise on the issue of our women and our izzat! No matter what age we live in; no matter what the world outside dictates; no matter what evil lies outside our door...we will never let you sully our izzat or our women's honour, Shahzada" (p.37)

This concept of izzat or honour is due to blind adherence to the traditions that govern the feudalistic Pakistani society. Habib Khan, Zari Bano's father, is also interpellated under this ideology of honour inherited from his father. Thus, following the interpellation of the capitalist / political ideology, instead of providing for happiness to his daughter, he makes Zari Bano a tool to hold on to his property and wealth and forces her to marry with Holy Quran.

\section{The Family ISA}

Habib Khan and Shahzada, the parents of Zari Bano are the representatives of the family ISAs which directly influence her and form her identity as the holy woman. Although the acts of her mother are not repressive as that of her father but she is unable to convince her husband to refrain from making her daughter 'the holy woman'. Her submissiveness reinforces the patriarchal setup that subjugates the rights of women. Shahzada points to her marginalized position in the family when she says to Habib Khan: 
Don't thank me.... I am just a puppet, a mere worthless woman to do your bidding. You and your father are the puppeteers, Habib. You hold my daughter's fate in your hands. What choice do I have? I can only swing and dangle along in whichever direction you pull and manoeuvre my strings (p.71).

These utterances clearly show that she is interpellated to accept this ideology that women have no say of their own and she passively tries to persuade her daughter that she cannot avoid her fate once it is decided by her father. Habib Khan's character is also an embodiment of an interpellated subject in a patriarchal society who believes that he possesses honour being a man by birth and he is the one who holds the power to prescribe codes of honour to be followed by the women of his family. He vocalizes his ideology when he claims:

Now that I have no son, to whom am I going to bequeath all this land? I am not going to hand it over to some stranger who happens to marry my daughter. This is our land, accumulated and paid for by the sweat and toil of my forefathers, down the centuries by different generations (p.66).

Habib Khan's ideology highlights the typical feudal mindset in Pakistan that values land and property so much that it doesn't allow strangers to cast an eye upon them even if their women remain celibate all their lives. So, as Althusser suggests that "there is no way out of ideology", Habib Khan also cannot hand over his land and property to a stranger even if doing so he has to sacrifice his beloved daughter's happiness. His land and his daughter, both are his honour and he realizes that by marrying his daughter to Sikandar, her suitor, he will lose control over them. Zari Bano also realizes that her father will not let his male ego hurt and will follow his tribal customs at any cost.

Zari Bano's belief that her father will not do anything against her will because he loves her so much proves Althusser's concept once again that she is "always already" a subject. She tries to resist her father as much as she can when her father informs her about her new role: "There is no way I will become a Holy Woman, father, I know what it entails and I am not cut out for that role. As you know I have hardly ever covered my head properly. I know very little about religion. I am very much a worldly woman. I cannot become a nun!" (p.79). On another occasion, she tells her father: "I want to be a normal woman, Father, and live a normal life! I want to get married. I am not a very religious person, as you know. I am a twentieth-century, modern, educated woman. I am not living in the Mughal perioda pawn in a game of male chess" (p.85). At the end, she herself explains that, "my father made me believe that he would 'sell the world for me' when in fact he eventually decided to 'sell' me to his male whims and ancient traditions"' (p.87).

Zari Bano's arguments with her father show her resistance towards interpellation of the 
family ISA that is "hailing" her to become a subject i.e. "the holy woman". She is obviously repressed by the dominant ISA of family that is suppressing her legitimate right to lead a normal life and get married. Although, her family seems liberal to some extent, Zari Bano is, nevertheless, raised in a Muslim family. Consequently, she is unable to confess her love for Sikandar in front of her father. When she argues with her father for her right to live a normal life and get married, she is accused of 'wanting a man' by her own father; "so you are saying that you want a man in your life?"(p.85). Zari Bano feels embarrassed and ashamed when her father directly refers to his daughter's intimate desires and sexuality; "her cheeks crimson with shame and shock, Zari Bano stared mutely at her father. Then her gaze fell as embarrassment and a torrent of boiling rage assaulted her body... the sexual connotations to his words had shaken her to the core" (p.85). A father's use of sexual connotation in his language towards his daughter is atypical in Pakistani society. By using such language he manipulates his daughter's ideology. In other words, he is "hailing" or interpellating her, as Althusser illustrates that this is the process by which language constructs a social position for the person who is "hailed". Habib Khan interpellates both his wife and his daughter by enforcing his ideology; Shahzada agrees to fulfill her duty as a dutiful wife and Zari Bano accepts his decision and becomes the holy woman. Zari Bano is interpellated to the extent that she even refuses to marry Sikander when he offers to marry her without her father's permission. Instead she decides to perform her role as a daughter and protect the 'honour' of her father.

Finally, Zari Bano, forced by this ideology of honour, becomes heiress to her father's land and accepts her role as a holy woman:

Here I stand before you, Mother, my father's Shahzadi Ibadat'. She spread her hands in a flourish. 'The Holy Woman. The woman he created by killing me. Did you not know that men are the true creators in our culture, Mother? They mould our lives and destinies according to their whims and desires". (p.87)

This vocalization by Zari Bano asserts Althusser's theory that she is "always-already" a subject in the patriarchal society and her life is controlled by the men in her family. To achieve socio- political motives the passive ideology of the "holy woman" is thus made natural to her in a way that she can't either resist or escape from. It is the same process followed in society to create truth claims which may be unjust to certain groups as in this case is the women.

\section{Conclusions}

This paper has focused on application of Althusser's theory of Ideology and Ideological State Apparatuses to study the power structures and the functions of ISAs in identity formation of Zari Bano, the protagonist of the novel "The Holy Woman". The 
critical reading of the text uncovers the life of Zari Bano directly affected by the decisions made by her parents, her grandfather and her suitor, who act as the agents of ISAs prevailing in Rural Sindh's society. The first research question is answered through the analysis of the role played by these agents of ISAs which 'hail' Zari Bano into a subject. The analysis reveals that the individuals' identities are always created by powerful social agents in patriarchal societies, such as Zari Bano's father, who force her to become his heiress through accepting the role of 'holy woman'. The investigation of family ISA, cultural/social ISA and political ISA in the text highlights various norms and beliefs of the people surrounding Zari Bano (second research question). Various moments of 'interpellation' are also identified in the text (with reference to third research question) that encourage the characters in the novel to act in certain ways and willingly accept the dominant set of morals, standards and realities of the society. Zari Bano's character is an embodiment of every woman living in Pakistani feudal society. She is interpellated by various ISAs that contribute towards her 'hailing' as a subject i.e. 'the holy woman'. Her conscious adherence to her father's decision indicates how women in a feudal society are interpellated and forced to accept pre-existing roles in the name of family's honour and if the situation demands from them they may offer themselves in sacrifice to maintain the male patriarchal ideologies.

This study is limited to the analysis of interpellation and ISAs only on Zari Bano and the characters closely related to her. There is a parallel story in the novel about Chaudhrany Kaniz and her son Khawar, and their relationship with Firdous, the woman Khawar wants to marry. Further research can be conducted to reveal the role of ISAs in interpellation of these characters in the novel. Again, the second part of the novel may draw attention of the researchers to explore the role of ISAs in further development of the identity of Zari Bano, from 'the holy woman' to a normal and married woman.

\section{References}

Althusser, L., \& Brewster, B. (2001). Ideology and Ideological State Apparatuses (Notes towards an Investigation). In Lenin and Philosophy, and other Essays. New York: Monthly Review Press.

Ambayec, Maria Shantelle Alexies E. (n.d.) Harry Potter and Althusser's State Apparatuses. COMA $192-$ F.

Arafath, Y. (2014). When Patriarchy Strikes: Exclusive Interview with Qaisra Shahraz. Writers in Conversation.1(1). February, 2014, retrieved from: http://fhrc.flinders.edu.au/writers_in_conversation 
Assemi, A. Asayesh, M. E., Dehghan, Siamak S. (2012). Application of Althusser's Ideology on "Clay”. World Applied Sciences Journal, vol.19:4, pp.588-594.

Barua, Protim P. (2014). A Critical Study of the Concept of 'Ideology': Based on Althusser's Ideology and Ideological State Apparatuses. International Journal of English Language, Literature and Humanities, vol.2:1.

Burke, P. \& Stets, J. (2009). Identity Theory. Oxford University Press.

Butler, J. (1988). Performative Acts and Gender Constitution: An Essay in Phenomenology and Feminist Theory. Theatre Journal, vol.40:4, pp.519-531.

Cixous, H. \& Catherine, C. 1986 [1975]. Sorties. The Newly Born Woman. Trans. Betsy Wing. Minneapolis: University of Minnesota Press, pp.63-132.

Davis, D. A. (n.d.) The Interpellation of Percy Munn. University of North Carolina at Chapel Hill, retrieved on May 24, 2015, from: http://englishcomplit.unc.edu/ journals/slj/davisonwarren.pdf

De Beauvoir, Simone. (1997). The Second Sex. London: Vintage Books.

Fiske J. (2003). Culture, Ideology, Interpellation, Modern Theory: An Introduction, New York, pp.1268-1273.

Fuery, P. \& Mansfield, N. (2000).Cultural Studies and Critical Theory. Oxford University Press.

Grimwade, J.C, Walker, D. W., Bartlett, M., Gordon, S \& Wood, C. (1970). Human Fetal Heartrate Change and Movement-response to Sound and Vibration. American Journal of Obstetrics and Gynecology, vol.109, pp.86-90.

Heywood, A. (2003). Political Ideologies: An Introduction. New York: Palgrave Macmillan.

Isran, S. \& Isran, A, M. (2012). Patriarchy and Women in Pakistan: A Critical Analysis. Interdisciplinary Journal of Contemporary Research in Business, vol.4:6, pp.835-859.

Jorgensen, M. \& Phillips, J. L. (2002). Discourse Analysis as Theory and Method. SAGE Publications.

Kiziltas, Ş. (2014). An Althusserian Review of the 'The Doll's House' by Katherine Mansfield. Atatürk Üniversitesi Sosyal, vol.18:2, pp.127-137. 
Lemley, Julie L. (2005) .Gendered Construction of the Female Identity. Journal of Undergraduate Research at Minnesota State University, Mankato, vol.5:1/14.

Lye, J. (1997). Some Post-Structural Assumptions, retrieved on June 24, 2010, from: http://www.brocku.ca/english/courses/4F70/poststruct.php

Medina, J. (2005). Language: Key Concepts in Philosophy. Continuum London New York.

McGee, C. (n.d.) Notes on Interpellation, retrieved on May 24, 2015, from: http://www.longwood.edu/staff/miskecjm/314interpellation.html

Ochs, E. (1993) Constructing Social Identity: A Language Socialization Perspective. Research on Language and Social Interaction, vol.26:3, vol.287-306.

Qadir, A. S \& Riaz, F. (2015). Gendered Political Identity Construction in Pakistani Television Talk Shows. FWU Journal of Social Sciences, vol.9:1, pp.20-28.

Protim, B.P. (2014). A Critical Study of the Concept of 'Ideology': Based on Althusser's Ideology and Ideological State Apparatuses. International Journal of English Language, Literature and Humanities, vol.2:1.

Sadati, S.S. (2013). The Influence of Ideological State Apparatuses in Identity Formation: Althusserian Reading of Amiri Baraka's "In Memory of Radio". International Journal of English and Literature, vol.4:10, pp.480-485.

Shahraz, Q. (2002). The Holy Woman. Islamabad: Al-hamra.

Tarar, G, M \& Pulla, V. (2014). Patriarchy, Gender Violence and Poverty among Pakistani Women: A Social Work Inquiry. International Journal of Social Work and Human Services, Practice Horizon Research Publishing, vol.2:2, pp.56-63.

Trudgill, P. 1974. Sociolinguistics: An Introduction. Penguin Books.

Tyagi, T. (2014).A Play of Ideological State Apparatuses in Identity Formation. Research Journal of English Language and Literature, vol.2:4, retrieved from: http://www.rjelal.com

Walby, S. (1990). Theorizing Patriarchy. Oxford, UK: B. Blackwell 
Walker, A. J. (1999). Gender and Family Relationships. In Handbook of Marriage and the Family, 2nd ed. Edited by Marvin B. Sussman, Suzanne K. Steinmetz and Gary W. Peterson. New York: Plenum Press, pp. 439-74.

Dr. Amna Saeed is an Assistant Professor in the Department of Humanities, COMSATS, Islamabad.

Azher Khan is Research Scholar in the Department of Humanities, COMSATS, Islamabad. 